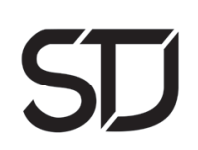

\title{
Justice for the dead
}

\author{
Silakhe Singata \\ University of South Africa \\ ssingata65@gmail.com
}

\begin{abstract}
The objective of this article is to reflect on the challenge issued by John D. Caputo, in his approach to the resurrection, to rewrite the history of the suffering with prayers and tears. In order to ground this reflection in the African context, the notion of remembering the dead in weak theology will be brought into conversation with the African traditional practice of venerating ancestors. This is all to approach an act of remembering the victims of the past which is different from historiography.
\end{abstract}

\section{Keywords}

John D. Caputo; risen body; remembering the dead; weak theology

\section{Introduction}

From the time of Dutch and British colonial settlement to the present, the land that is now known as South Africa has been marked by struggle and domination: first through colonization, then through the domination of black people through the Apartheid regime, and in the present in a country that has inherited the racial and economic divisions of its past.

The "fallist" movement of 2015 has sensitised the South African public to the fact that the structural injustices of the present are directly connected to the injustices of the past, brought about through colonialism and apartheid. South Africa is in some ways a discontinuation of these two historical events - in that both have formally and legally ended - and yet also a continuation of them, both because the racial divisions in this country can be traced back to both (but arguable most notably to apartheid) and because the economic inequality along racial lines in South Africa can be traced back to both (through land dispossession and the economic 
exploitation of Africans). The break between the old South Africa and the "New" South Africa is not a radical as might have been thought in the wake of the first democratic elections in 1994.

Therefore, the central argument of this article is that the past must be saved for the present to be saved, and that this would open us up to the possibility of a future which radically breaks with the unjust past and present. This article seeks to discuss and examine this problem theologically. In conceptualising a way in which the past can be saved, this article turns to the Christian notion of the resurrection of the dead, which, as will be discussed in this article, is a way in which the notion of saving the past has tended to be conceptualised in the Judeo-Christian scriptures, as well as much of Christian eschatology. It also turns to the African notion of Ancestral veneration. The connection between the resurrection of the dead and a radical break with the present world in the Judeo-Christian biblical tradition is appropriated in this article for the South African context in a concrete way by grounding this theological discussion on the question of how justice for those who have died in the South African context, from tyrannical power and structural injustices in South Africa's history (and present) of struggle, domination and systemic injustices. This article will intentionally leave the identities of the dead in question open, in keeping with idea that it is the responsibility of the South African public, particularly theologians, to do the difficult task of going through history to see, and to be seen by, these hidden victims, and rewriting history from their vantage points. Passing mention will be made of both the Sharpeville massacre (1960) and what has been termed the Marikana massacre (2012) as a concrete demonstration that the break between the Old South Africa and the New South African was not that radical (as both have massacred black bodies). This point could have been concretized through referring to the continuation of landlessness of many black people in South Africa today, however these two massacres are chosen in keeping with the topic of resurrection of the dead.

The above mentioned research problem will be addressed through John D. Caputo's reading of the resurrection of the dead as the rewriting of the history of the suffering with prayers and tears, a notion that in his most 
recent publication he has referred to as "a theopoetics of transacendence." While this article is not primarily about Caputo's work it will nonetheless address him substantially; and in particular his later corpus of theological writing. The primary focus is to address past injustices done to victims who have been laid low to the point of death, by means of a radical conception of the theological notion of resurrection from the dead. The article seeks to address the need for a radical break with the old South Africa by means of a radical theology. Caputo's approach is adopted primarily because it takes what could easily have been framed as a theodicy question, and shifts it to a question of anthropodicy: the challenge of repairing the past is not left to an uber-divine other, but is the responsibility of human beings. Here the name of God is the name of that which puts us into a position of accountability.

Since Caputo is an American thinker, and this a decidedly South African study, it would be careless to attempt to directly apply Caputo's ideas as if these two concepts are identical. The approach to be followed will put Caputo's conception of the resurrection of the dead into conversation with the African practice of veneration of the Ancestors. This will not be done in order to conflate resurrection with Ancestral veneration, but rather in order to affect a theological reflection on saving the past that is genuinely African.

\section{Weak theology}

Weak theology is a form of radical theology that was developed by John D. Caputo, initially argued in the books, The Weakness of God, The Insistence of God and The Folly of God. Caputo develops this unique take on Radical Theology by approaching theology through Derridean deconstruction. This is in order to approach theology in a way that is other than onto-theological. This term is used by Caputo to refer to theology that is based on a metaphysics of presence. ${ }^{2}$ It is a theology which argues against theology

1 J.D. Caputo, Cross and Cosmos: A Theology of Difficult Glory (Bloomington, Indiana University Press, 2019), 114.

2 As early as 1987 Caputo refers to the onto-theo-logic in connection to a metaphysics of presence, which he criticises in favour of the Kierkegaardian notion of repetition. Caputo's work seeks to re-describe existential reality in the light of the difficulty of the "flux." What Caputo means by "flux" is the flow of time, and the transience that 
making metaphysical claims, even (or especially) about God. This is a denial of the Enlightenment idea that absolute truth, or the metaphysical reality can be accessed by one disciple or another (including theology), through one hermeneutical approach or another, or even through revelation. So, no act of knowing can make recourse to metaphysics in order to prop up its epistemology. Therefore, eschatological thinking in this approach would have to talk about the end from a position of non-knowing.

For his weak theology, Caputo draws on the ways in which French philosophers Jacques Derrida and Gilles Deleuze conceive of the notion of the event. ${ }^{3}$ For Derrida, the event refers to the breaking in of something totally new (the wholly other), "the breaking into our familiar world of something completely amazing, completely unexpected, which breaks up our horizons of expectations." "So for Derrida, event is conceptualized as a movement from the outside to the inside, an incoming. For Deleuze event is described the opposite direction, so to speak, as "the coming-out ... or bursting out of something we did not see coming, something unforeseen, singular, irregular, even a bit odd." ${ }^{5}$ Caputo hold both these conceptions together, to think of the event es something which, in somewhat apocalyptic and eschatological sounding Husserlian terms, can be described as "a moment ... that tears up time" or "the annihilation of the world." ${ }^{6}$ For Husserl this does not refer to a metaphysical destruction of time and the

comes with it. Caputo argues that the philosophical tradition, under the influence of the Greeks has tended to make sense of the flux as Platonic recollection. Recollection is a backward movement, and this can be seen in the fact that the Greeks, according to Caputo, thought that eternity is lost the moment beings fall into time (the flux), and that that original eternity is to be regained. Furthermore, Caputo posits that the Greeks were of the mind that when new knowledge is acquired, it is in fact being recollected from when it was known in eternity. In this view, flux (movement) or time is a consequence of falling out of eternity; it is a mistake, a defect, but it is not permanent - there must be a return to eternity (recollection). So, according to this orientation, eternity is the opposite of flux (movement and temporality) - eternity is a timeless, static Presence; it is the metaphysics of presence. This is the metaphysics behind ontotheo-logic. For a fuller treatment of this topic, see J.D. Caputo, Radical Hermeneutics: Repetition, Deconstruction, and the Hermeneutical Project (Bloomington: Indiana University Press, 1987), 10-35.

3 J.D. Caputo, The Weakness of God: A Theology of the Event (Bloomington: Indiana University Press, 2006), 109.

4 Ibid., 109

5 Ibid., 109

6 Ibid., 109; Radical Hermeneutics, 43-44 
world, but rather the destruction of a hermeneutical unity held to be the way the world and time should be conceived. Simply put, events in Caputo's theology have to do with the possibility of a different way for the world to be the world.

Caputo works out a theology in which the name of God does not refer to a divine agent or being, but is rather a name that harbours a cluster of events that are both a promise and a threat of a different way for the world to be: they are a promise because it is always possible for the world to be better than it is, in ways that have not been imagined, but they are a threat because the world could always be worse. Also, the possibility for things to get worse (threat) is an irreducible structural necessity for the possibility for things to get better (promise).

Following Derrida's lead, Caputo discusses events such as the gift, forgiveness, hospitality, justice, and a democracy to come. ${ }^{7}$ In brief, by means of the above mentioned promise/threat nature of events, they exert a certain appeal, call or demand, but this is a paradoxical demand, because it is of the structure of a "sovereignty without force." ${ }^{\text {" What Caputo means }}$ by this is that events do not have access to a police force, or an army in order to force people into acting out the reality that they promise/threaten. This means the force of an event is a "weak force," the force of an appeal or provocation. So since the name of God, for Caputo, is not the name of a powerful agent, being or entity, but is the name of an event, or rather a cluster of events (forgiveness, hospitality, the pure gift, justice and a democracy to come, to name but a few), God has no power to ensure that these events become a reality. God has no police force to enforce God's will. God only has a weak force of a provocation, or a call of the event. In this article I will limit myself to discuss the event of the resurrection of the body.

It is important to note that the "events" that weak theology is attuned to are events that take place within theology, and these are also the provocation or call that tend to result in the emergence of theologies as a response or reaction. So here we can see that weak theology is an approach that

\footnotetext{
7 The Weakness of God, 29.
}

8 Ibid., 28-29. 
wrestles with the thought that that which communities of faith hold sacred did not fall out of the sky readymade, but that they emerged in history, and continue to develop as history continues - theology is from below, not from above. Theology is a historical contingency through which the event "tries," so to speak, to happen. ${ }^{9}$ With this in mind, it is helpful to think of weak theology as a doing of theology in the space between the event and one of its historically contingent expressions called theology. ${ }^{10}$ In order to appreciate how this is relevant to the topic of this article - resurrection of the dead - I will now discuss miracle narrative's in weak theology.

\section{Miracles}

Caputo takes the kingdom of God and the miracle stories as they are described in the New Testament as being about transformation, reformation and rebirth; he takes them to be about metanoia. ${ }^{11}$ The New Testament stories about resurrection - be it the resurrection of a widow's son, the resurrection of Lazarus or the resurrection of Jesus himself are no exception. With respect to the narrative about the resurrection of Lazarus in John 11, he writes:

This singular transformation from death to life contains in a preeminent and paradigmatic figure the very substance of what Jesus is always doing in all of his works and deeds; it describes, in a word, what he is always teaching in all of his sayings. Even as the creative act of Genesis is a movement from a lifeless wild to a world teeming with life, the work of Jesus is to assist in the reversal of death into life

9 Caputo, in The Insistence of God: A Theology of Perhaps (Bloomington: Indiana University Press, 2013) writes: "I posit that there are midnight moments when confessional theologians toss and turn with the haunting thought that what they call a gift of grace is in fact an accident of birth - that, had they been born in another time and place, they would have entirely different things inside their heads than the things they defend in their daytime theologies" (72).

10 J. D. Caputo, "Bodies Still Unrisen, Events Still Unsaid." Angelaki: Journal of Theoretical Humanities 12 (2007): 77.

11 Caputo uses this Greek word to describe the sort of transformation that takes place in the Gospels when Jesus acts. This is exactly the point of the miracle narratives in the bible, for Caputo: to portray God as a God who changes things for the better. For a fuller treatment of metanoia, see J.D. Caputo, The Weakness of God: A Theology of the Event (Bloomington: Indiana University Press, 2006), 127-154. 
... Jesus is the locus of divine transformation, the prophetic centre of the transformative energy of the kingdom, by coming in contact with which all things are made new, which is what the kingdom means. ${ }^{12}$

For Caputo, ${ }^{13}$ there is an appeal or a claim (an event) that issues from these strange pre-Copernican stories; for him, there are "solicitations that call for a response," for our response. So, for Caputo, the scriptures are truth, but not in the same why that scientific theories, or historical accounts are true: the scriptures do not contain propositional truth, but rather the truth of an event. An event, with respect to the scriptures, refers to the appeal that issues from the scriptures; it refers to the way the strange stories in the scriptures lay claim on us, and provoke us to bring their truth into existence through our actions. The truth of the scriptures, for Caputo, is not in the story itself but rather in the way of "being-in-the-world" - or even a different way for the world to be - that these stories disclose; it is a phenomenological truth. ${ }^{14}$ For him, the truth of the scriptures is truth in the form of an appeal or call, that needs our hospitality, through our listening and responding. These hermeneutical assumptions are important in Caputo's take on the resurrected body in weak theology.

Caputo then takes miracle narratives in the New Testament as one way in which this different way for the world to be has been pictured or imagined in a literary sense. So, for Caputo, a miracle narrative is a way of imagining the unmanageable - namely, a different way for the world to be the world. Miracle narratives are viewed here as a way to see what no eye has seen, or to hear what no ear has heard. Caputo speaks of these miracle narratives as "exercises in freedom in which the human imagination breaks the bonds of logic and physics and dreams of being otherwise and of what is otherwise than being." 15 This definition of a miracle is important when considering Caputo's take on the risen body, because logic, the law of physics and biology render it impossible for dead bodies to rise to life. However with this definition of a miracle, scepticism of the possibility of a physical or

12 The Weakness of God, 238.

13 Ibid., 117.

14 Ibid., 118.

15 Caputo, "Bodies Still Unrisen, Events Still Unsaid," 75. 
literal resurrection is suspended, not for it to be dismissed in favour of the supernatural, but rather in order to direct the attention to the possibility of a different reality for dead bodies that is communicated through it; a reality that opposes the reality which caused their dying. It is the stubborn refusal to part with the body, in contradiction to a reality which has destroyed that very body, that interests Caputo in his take on the risen body.

Caputo insists that there should be a distinction between the event and its embodiment, and he argues that the way to go about maintaining this distinction is through "transcendental suspicion." ${ }^{16}$ For Caputo, ${ }^{17}$ the risen body embodies or incarnates the event, but is not the event itself. It is not the ultimate expression of the event. No embodiment of the event is the ultimate expression of it. Things are never said and done when it comes to the event. If the risen body is viewed as that which happens, then the event is that which happens in what happens - it is an occasion to reflect on the possibly of a different reality for dead bodies. The event is the totally unexpected possibility that the notion of a resurrection of the body imagines.

This is perhaps already a clue that Caputo is not interested in defending or opposing a literal bodily resurrection of Jesus Christ or anyone else's, though he, no doubt, has an opinion on the subject. However, his choice of words shows us that what he is doing is different from what historians have done with miracle stories after the Enlightenment. He is arguing that we should turn to the victims of the past and rewrite their histories; he is doing theology from bellow. ${ }^{18}$

Through this transcendental suspicion, he avoids two ways of speaking from on high: (1) he avoids speaking from the heights of biblical inerrancy or fundamentalism, in which the bible is seen as though it gives people an epistemological advantage; (2) he also avoids the trap of demythologizing

16 Ibid., 76.

17 Ibid., 76.

18 He states that he "speak[s] of 'suspicion' rather than 'criticism' because 'criticism' comes from on high, speaking from a higher critical standpoint, while 'suspicion' is practiced from below, exercising a cautionary dubiousness," in Caputo, "Bodies Still Unrisen, Events Still Unsaid," 76. 
the miracle stories by reducing them to a single kerygma (Bultmann), ${ }^{19}$ or the reducing the bible to some ethical rule(s) such as the golden rule (Kant) ${ }^{20}$ For Caputo such approaches to the miracle narratives are to miss the point of the narratives - imagining the unimaginable. This article is an engagement in theological reflection from below, from six feet under, from the grave or hades, the realm of the dead.

\section{Resurrection of the body}

Caputo correctly points out that the notion of a resurrected body is not the same thing as a notion of an immortal soul. With the doctrine of the immortality of the soul, the soul is separated from the body at death; ${ }^{21}$ death is accepted and accommodated. The notion of a risen body, however, "is the refusal to separate oneself from the body." 22 In the notion of the risen body there is a negation of the body's negation, namely death. The risen body is protest. In this notion, death, and all the bodies limits with it, is transcended. ${ }^{23}$ The risen body "is able to pass through walls, to appear instantly in distant places and just as instantly to disappear." 24 Through the notion of the risen body, we are confronted by a notion of embodiment which contradicts everything we know about embodiment. Caputo sees this as illogical, and this is a good thing for him: if the risen body is supposed to be an image of a reality that is other than our own (which is logical), it is supposed to be this way. If the opposite of this illogical reality is our normal world where bodies are crucified by empire, then this folly the folly of God - is protest. Caputo writes:

19 For a critique of Rudolf Bultmann, see Dale B. Martin's Biblical Truths: The Meaning of Scripture in the Twenty-first Century (New Haven and London : Yale University Press, 2017), 18-23.

20 For a brief sketch of the development of Eschatology, as well as a discussion Immanuel Kant's notion of eschatology as the moral destiny of mankind, see Wolfhart Pannenberg's "Modernity, History, and Eschatology," in Jerry L. Walls (ed.), The Oxford Handbook of Eschatology (Oxford: Oxford University Press, 2007), 495.

21 J. Moltmann, The Coming of God: Christian Eschatology (Minneapolis: Fortress Press, 1996), 59. Caputo, "Bodies Still Unrisen, Events Still Unsaid," 78.

22 Ibid., 78.

23 Ibid., 78-79.

24 Ibid., 79. 
The transfigured body is woven from or a construction made out of events. It projects a body that represents the crowning triumph over the body that was crowned with thorns, that is now invulnerable to Roman swords and Roman nails and the blows of the soldiers. ${ }^{25}$

To be clear, Caputo does not ground his reflection on what would be for him the onto-theo-logic of a body that has been brought back from the dead (biblical literalism), or, to put it differently, he is not working from a "theology of transcendence," but is working instead from a "theopoetics of transascendence." ${ }^{26}$ A theology of transcendence would protest against murder from the position of glory and power of being risen up. A theopoetics of transascendence on the other hand works from the weakness of being victimised. Caputo calls this the impossibility of murder. When explaining this he writes:

[T] he arm of the murderer cannot reach as far as the infinite depth, dignity, and defiance of the victim, the insistence of the no that issues from the victim's face, physically destitute and defenceless before the bodily assault of the murderer but removed by an infinite distance beyond the murderer's reach ... Murder does not reach as far as the invisible alterity and untouchable freedom of the other ... The impossibility of murder is a theopoetic or phenomenological impossibility which cannot diminish the glory. ${ }^{27}$

The notion of resurrection of the dead did not exist in the earliest biblical material - which would have been of pre-exilic origins. ${ }^{28}$ The first time it appeared in the Judaeo-Christian tradition was in the post-exilic era, as a result of the theodicy question: how can God be a God of justice if his faithful servants are unjustly killed, and their murderers live long and prosperous lives without being judged? God can only be just, if God's justice is greater than death. ${ }^{29}$ In other words, even from its origins the apocalyptic notion of the resurrection of the dead was primarily about

25 Ibid., 81.

26 Cross and Cosmos, 114.

27 Ibid., 114.

28 K. Nürnberger, The Living Dead and the Living God (Pietermaritzburg: Cluster Publications, 2007), 232.

29 Ibid., 234-235. 
the righteousness of God..$^{30}$ It would not be a stretch to say that even in its earliest biblical appearances, resurrection means that God remembers every single body that is broken by imperial power. God protests the unjust imperial order by raising the dead.

And so even the New Testament notion of the resurrected Jesus means that the one who was crushed was remembered by God. God defied Rome by raising Jesus. If Eucharist is a meal that is eaten to remember the broken body, and its braking, then Eucharist is participation in God's act of insurrection. Participation in a meal that commemorates crucifixion - a tool of imperial intimidation - is not to romanticize suffering; rather it is a refusal to be intimidated. When discussing the Eucharist, M. Shaun Copeland writes:

Our daily living out, and out of, the dangerous memory of the torture and abuse, death and resurrection of Jesus Christ constitutes us as his own body raised up and visible in the world. As his body, we embrace with love and hope those who, in their bodies, are despised and marginalized. ${ }^{31}$

There is a dangerous memory of bodies that have been crushed by power, beginning with the body of Jesus, as well as all the other bodies, and for the purposes of this reflection, especially African bodies. Eucharist is about remembering the dead victims, and this is precisely that which happens through the notion of the risen body.

If the question were asked, how do we talk about God after Marikana, and after the Sharpeville massacre? Then the answer offered in this article is that we can only talk about God by remembering the dead, and the manner of their dying. On this point I will briefly discuss irreparable loss and ruined time, as this is a key point in the argument that Caputo makes about resurrection in the Weakness of God.

30 J. Moltmann, The Crucified God: The Cross of Christ as the Foundation and Criticism of Christian Theology. 40th Anniversary ed. (Minneapolis: Fortress Press, 1973), 247-248.

31 M.S. Copeland, Enfleshing Freedom: Body, Race, and Being (Minneapolis: Fortress Press, 2010), 126-127. 


\section{Irreparable loss and ruined time}

Similarly, to how an event is that which "escapes the order of economy," so does irreparable loss; with the difference being that an event is a gift/giving without measure (unconditional giving), but irreparable loss is destruction without repair, unlimited loss, "taking away, without compensation, remedy, or redress." ${ }^{32}$ Irreparable loss refers to meaningless suffering - it has no metaphysical reason or eschatological justification. Caputo is not even referring here, to suffering that ultimately leads to one blessing or another, such as a person growing up in poverty, only to have those childhood conditions build character in that person, which will ultimately lead to some sort of success. This is just unconditional suffering. It in turn leads to what Caputo calls ruined time. Of this he writes:

Of this irreparably ruined and irrecuperable time we will never be able to take a long view and say, "It was all worth it." There is nothing that makes it worth it, nothing with which it can be "compensated." This is not the pain that pays off, but the misery of pure loss, of disaster. A child born with AIDS, whose life is short and painful, which no one can justify or compensate, which one can only try to comfort or ameliorate. The innocent victim of a crime, like a child inadvertently caught in a crossfire between warring drug lord on an inner-city street. ${ }^{33}$

Other examples that Caputo mentions in passing are the events that happened at Auschwitz, Belfast, Kosovo, West Band, and all such places where horrible things of that nature occurred. ${ }^{34}$ Reading this from an African point of view, I cannot help but think of irreparable loss in, Africa; suffering that was brought about through European colonial expansion, as well as through the North-Atlantic slave trade; suffering that was brought about through Apartheid, as well as the persisting dehumanization of black people in its wake, as it can be clearly seen, for example, in the living conditions in the informal settlements all over South Africa. The rape and murder of Uyinene Mrwetyana in a post office in Cape Town is yet

32 The Weakness of God, 244.

33 Ibid., 243.

34 Ibid., 242. 
another case of irreparable loss. They result in what Caputo calls ruined time. Ruined time, for Caputo, is ruined forever. There is no going back in time to repair or fix that time. All the massacres, such as the one at Sharpeville, or the one in Marikana, all the rapes, such as the rape and murder of Uyinene Mrwetyane, will forever already have happened. The ink is dry, as it were.

Moltmann wrestles with this concept of ruined time in his eschatology, when he writes about what he calls "the day of days." He writes:

"The day of his coming" is supposed to be a day like all other days. It is to take place in time. So, in Christian tradition it has often been called "the last day". But the day is determined by what happens in it, by the coming of the Lord in his eternal glory. This breaks off the time of transience and ends time in time. If this last of days is also the dawn of the eternity of the new creation, then it is more than a day in the calendar. Since it is the day of God's coming, it is rightly called "the day of days"; for the eternity which appears on this day is simultaneous to all days and lights up all the nights of world history (emphasis added). ${ }^{35}$

The "nights of world history" that Moltmann refers to here are instances of that which Caputo has referred to as ruined time and irreparable loss. For Moltmann there is a day that will somehow repair ruined time. He continues:

That is why the living are to experience it as "transformation", the dead as "raising"; and for both the living and the dead it will mean a "transfiguration" in the radiance of the divine glory. As the day of the Lord it is not the "last day" in a sequence of days and the times. It lies athwart all the days and times. It will come not merely "from ahead," as it were, but also "from above." It will happen not only in time but also to time. ${ }^{36}$

So, for Moltmann, something happens to time itself; time is healed or transfigured. For Moltmann, ruined time must be healed. What Moltmann

35 Moltmann, The Way of Jesus Christ, 327.

36 Ibid., 327. 
argues for at times overlaps with what Caputo posits, but is also dissimilar with it at very interesting points. What they have in common is that they both see resurrection as transformation, however the content of that transformation differs: for Moltmann it is transfiguration, or the fixing of those ruined moments or rather of ruined time; for Caputo it is rebirth, restart, new time and new beginning. ${ }^{37}$ This will be returned to below, in connection with Jesus resurrection. At this juncture, it is important to discuss remembering of the dead, so that the connection can be drawn between the biblical notion of resurrection, and the African notion of venerating the Ancestor, which in turn will connect Caputo's notion of saving the past with African struggles for justice.

\section{Resurrection and remembering the dead}

On the point of remembering the dead, Caputo, following the thinking of Walter Benjamin, writes:

We are carried by the wings of historical desire above the constraints that time and being place upon us, to "brush history against the grain," as Benjamin says, across the - alas irreversible - flow of moments, to a moment that is no longer there so as to undo the damage and destruction, to stay the hand of the oppressor. ${ }^{38}$

This, of course, does not mean that the past is "altered" or "annulled," but that it is "saved." ${ }^{39}$ This is about writing or rewriting history, "with prayers and tears." 40 This follows the previous points, because we can only weep as Jesus did at the grave of Lazarus, if we love the dead, or find solidarity with them. Caputo also writes:

The eyes of the other are not the eyes that we can see but the (invisible) eyes that see us, that look back and behold us. There is an irreducible distance in the proximity of the neighbour, and the two together co-constitute the phenomenon of the other person,

37 The Weakness of the God, 248.

38 Ibid., 253.

39 Ibid., 253.

40 Ibid. 
as opposed to a physical object that we can dissect, break open, and analyse. The gas chambers are not large enough to contain this infinity. The swords of the Roman soldiers, the clubs of angry Mississippi mobs are not long enough to reach the one lifted up above them. There is an unreachable height in the one laid low. They live on and on, in memory, in literature, in the hearts of the aggrieved, where they attain new reality, a new being. They cannot die even though they were murdered. ${ }^{41}$

This article argues for a remembering of the dead, a rewriting of history that is cognizant of the eyes of the dead that gave at us. What Caputo here refers to as "a new being" that is attained by those who have been murdered when they are remembered by those who are living, is being conceptualized in the South African Context.

In the South African context, Bantu Steve Biko, writing during apartheid, wrote:

One writer makes the point that in an effort to destroy completely the structures that had been built up in the African Society and to impose their imperialism with an unnerving totality the colonialists were not satisfied merely with holding people in their grip and emptying the Native's brain of all form and content, they turned to the past of the oppressed people and distorted, disfigured and destroyed it. No longer was reference made to African culture, it became barbarism. Africa was the "dark continent." Religious practices and customs were referred to as superstition. The history of African Society was reduced to tribal battles and internecine wars. There was no conscious migration by the people from one place of abode to another ... No doubt, therefore, part of the approach envisaged in bringing about "black consciousness" has to be directed to the past, to seek to rewrite the history of the black man and to produce in it the heroes who form the core of the African background. ${ }^{42}$

Here, Black Consciousness and Caputo's approach to resurrection overlap. So, if one speaks of the coming Messiah raising the dead in the discourse

41 Cross and Cosmos, 115.

42 S. Biko, I Write What I Like (Johannesburg: Picador Africa, 1978), 32. 
of weak theology, one is already speaking about what Biko, in a different discourse, calls "Black Consciousness." Resurrection in weak theology is to remember the dead, and to rewrite history from the perspective of the victims. Resurrection, in weak theology is to do theology from below. To continue not only the theme of remembering the dead, but also theology from below I know to my attention to abaphantsi (which literally translates: those who are below) - this is one of the ways in which the ancestors are referred to. I am turning to the discussion on the African notion of the Ancestors on a discussion about weak theological interpretation of resurrection in an African context in order to allow African ways of thinking to be present in a discourse about the future of Africa.

\section{Ancestors}

The appropriate place to begin is with community, because life, in the African context tends to be viewed in a communal sense. This can be seen in the African notion of uBuntu: umntu ngumntu ngabantu; which I usually translate, "a person acquires personhood in relation with other persons." So, with ubuntu in mind, the moment you talk about an individual (umntu) there is already an expectation of a connection with other people (abantu) be it the individual's family or community at large. This is crucial when discussing ancestors in African thought. This is because an ancestor can only acquire the status of ancestor by being recognised as an ancestor by that ancestor's living relatives.

The dominant belief in the idea of ancestors, who are also sometimes referred to as "the living dead," is not the notion of the individual surviving death (though this is doubtless part of it), but rather the notion of an individual's relationship with that individual's community or family surviving death. For the ancestor, death is not rest, but rather it is to enter a new level of service for the living. John Mbiti states that many have mistakenly thought of African religion as ancestor worship. ${ }^{43}$ Mbiti argues that acts done for the dead, such as the building of shrines, leaving of food and drink at their graves etc., should be seen not as acts of worship, but rather as respect for

43 J.S. Mbiti, Introduction to African Religion (Long Grove: Waveland Press, 1975), 18. 
the dead. ${ }^{44} \mathrm{He}$ argues that such acts show a belief that the dead continue to exist and that they still care about their surviving loved one's (their community). These acts, Mbiti argues, are aimed at ensuring that the dead are not forgotten. ${ }^{45}$ This notion of remembering the dead is indispensable in the African notion of the ancestor. This point will be returned to bellow. Before that, however, it is important to briefly discuss the notion of the authority of the Ancestor.

\section{Authority}

In African thought, it is usually the case that not everyone is believed to become an ancestor after death. Only those who meet the following requirements: those who live through the crucial stages of life (initiation, marriage and having children), those who die of natural causes at an old age (a man is considered old if he is married and has children), rather than those who die as victims of murder of through an accident. ${ }^{46}$ Of Couse, there are some differences in certain parts of Africa, but for the most part, these are the generally accepted requirements. Anyone who has gone through these stages acquires seniority in the family and community at large. This in turn means that those who became ancestors after dying were senior members of the family and society, and therefore were authority figures.

Authority is not considered as an abstract concept that merely regulates social interactions and relationships. Rather it can anachronistically be described as something that is perceived as a metaphysical reality. For example, the baSotho people talk about seriti, as a unique attribute of an individual which is strong if the person in question has a high level of authority or dignity, and weak when the person in question is not authoritative or exudes little or no dignity. The amaXhosa people speak of isidima to denote the very same thing. Seriti/isidima usually refers to either a person's character or a person's spirit (sereti/isithunzi). ${ }^{47}$

44 Ibid., 18.

45 Ibid.

46 D.B. Stinton, Jesus of Africa (New York: Orbis Books, 2004), 113.

47 See V. Vellem, “Serithi/Isidima.” Scriptura 104 (2010): 317-318. 
For the baSotho, and amaXhosa, it is seriti/isithunzi (a shade connected with dignity, which is also the vital force of a person) that is the quality in an individual that becomes an Ancestor after death. ${ }^{48}$ It is by virtue of the fact that an individual had authority and dignity while alive that that individual can acquire the authority and dignity which comes with being an ancestor after death. This authority, however, does require that the ancestor be remembered by the ancestor's surviving kin. An ancestor is usually remembered up to the fourth, the fifth or even the sixth generation and will then fall into vagueness and obscurity. ${ }^{49}$ Spirit and seriti/isithunzi can be used interchangeably when discussing that in the individual which survives death when the individual becomes an Ancestor, and it is the same thing as dignity and authority (sereti/isidima). However, when I talk about life after death below, I will drop the terms sereti/isidima, only for the sake of brevity. The concepts they denote with continue to be assumed.

\section{Ancestor veneration}

Many have tended to think of African religion as Ancestor worship. This is, however, a misrepresentation..$^{50}$ As has been stated above, acts done for the dead, such as the building of shrines, leaving of food and drink at their graves, should not be seen as acts of worship; but should rather be taken as an indication that firstly, African's believe in the continued existence of their dead loved one (specifically those who become Ancestors after death), and that the loved one is still interested those who survive him after death; and secondly, that these are acts of respect that are aimed at ensuring that the dead are not forgotten for generations to come. ${ }^{51}$ So again, the memory of the dead is very important where Ancestors are concerned in African culture. This, of Couse, is a memory of those who met the criteria discussed above before dying, and not the dead at large. This point will be taken up below. However, prior to that, it will be helpful to take a brief detour from

48 Vellem, "Serithi/Isidima," 318.

49 Nürnberger, The Living Dead and the Living God, 26.

50 Mbiti, Introduction to African Religion, 18.

51 Ibid., 18. 
Ancestors, in order to discuss death in general and the afterlife in African traditional thought.

\section{Death and the after life}

In African Traditional thought, it is commonly thought that between the statuses of God and human beings, there is the status of the spirits. ${ }^{52}$ Amongst the several different kinds of spirits, there are human spirits, and among these human spirits there are the spirits of people who died long ago, and the spirits of people who died recently. ${ }^{53}$ The spirits of those who have died recently are thought to retain closeness with their loved ones who survive them. They are remembered all the way to the fourth and even fifth generation after their death. These are ancestors.

When these spirits are no longer remembered by name, in some contexts they are believed to become ghosts or wandering spirits, or in other contexts they cease to exist as personalities and become dynamistic power which can be used for good or for harm by sorcerers or witches. This fate is also believed to befall the spirits of those who have died recently but have not received the proper funeral rites. ${ }^{54}$ In any case, it is important not to conflate the African Traditional Religious understandings of the afterlife with any Christian notion of the afterlife, or the resurrection.

The idea of a judgement after death is not common in ATR thought, which is a strong indicator that it was not common, or maybe even non-existent in pre-colonial Africa. ${ }^{55}$ This leads Mbiti to posit "that on the whole African Religion has neither heaven nor hell, and neither rewards nor punishment for people in the hereafter." ${ }^{56}$ So unlike Judeo-Christian eschatological notions of resurrection or afterlife, the African understandings of the afterlife are not concerned with putting things to right, or the victory of

52 Ibid., 70.

53 Ibid., 70-78.

54 Nürnberger, The Living Dead and the Living God, 25.

55 Mbiti, Introduction to African Religion, 123-124.

56 Ibid., 124. 
righteousness over unrighteousness. Death does not lead to glorification, and it and the afterlife are not desirable in African religious thought. ${ }^{57}$

\section{The body at death}

The spirit is believed to separate from the body at death. The spirit would still resemble the body in terms of appearance. ${ }^{58}$ The distinctions between the spirit and the body do get blurred at times. ${ }^{59}$ For example, in some African societies, when people die, they are buried with food, drink, weapons and tools, and will need all those resources. ${ }^{60}$ That a spirit can be nourished by physical food and make use of physical tools demonstrates this blurring. Perhaps it is an indication that the category of "spirit" might not have been thought by pre-colonial Africans in the way that it is thought of in postenlightenment western thought: as immaterial or incorporeal. In fact there are scholars that argue that "spirit" is a misleading term when talking about Ancestors, and that we should instead speak of "presences." ${ }^{16}$ This also means that this is different to the deprecation of the body or the natural or physical that we find in platonic thought and much of Christianity. In as much as the flesh or body is buried, and rots away, that which remains whatever the appropriate nomenclature (spirit?) - is not less human but is the full person it was. So long as the dead persons dignity and authority survive death through the recognition of that person's authority by that person's surviving kin, then the full person continues to exist after death, in a kind of existence that does not conform to the material/immaterial dichotomy. It is in the continuance of the persons authority that a person

57 Nürnberger, The Living Dead and the Living God, 24-25.

58 Mbiti, Introduction to African Religion, 124-125; Nürnberger, The Living Dead and the Living God, 24.

59 Mbiti, Introduction to African Religion, 125

60 Ibid., 123.

61 This argument is made by P. T. Muze and is partially followed by Nürnberger. Mtuze argues that what is often thought of as a person's spirit is, in African thought, not a part of a person that that has been stripped of the body and exists in some incorporeal spiritual dimension, but can instead be more appropriately thought of as the full person, but without vitality. For more on this see P. T. Mtuze, The Essence of Xhosa Spirituality and the Nuisance of Cultural Imperialism (Johannesberg: Vivlia, 2003); and to see where Nürnberger disagrees with Mtuze on his terminology, see his footnotes in The Living Dead and the Living God, 27n.91. 
goes on after death, not their vitality - which ends with the body. This point ties in with what was discussed above about community: authority only exists in community, and if the ancestor "lives" on after death through his authority, then the ancestor needs community in order to "live" on after death. This is way some cultures, such as the Venda culture, the Ancestor can be ritually killed by being excommunicated from the community and being forgotten, or even through sorcery. ${ }^{62}$

This is a way of remembering of the dead that does not completely cut ties with corporeality. The African experience of seeing one's Ancestors in visions and dreams in many ways overlaps with and diverges with the post-resurrection appearances of Jesus. These overlaps and divergences will be discussed so as to have an idea how the African Traditional notion of the Ancestors can contribute to a reading of resurrection that uses the methodology of weak theology.

\section{The living dead and the living Christ overlapping}

Firstly, both resurrection of the dead and the African notion of the Ancestor involves some kind of a remembering of the dead: in the case of the Ancestor, the act of remembering is done by the family or community; and in the case of resurrection, God remembers the dead.

Second, for both respectively, as far as the body and materiality is concerned there is some kind of continuity and discontinuity. The Ancestor who can still be nourished by the food that the Ancestor's kin leave for the Ancestor, or use the tool's and weapons they leave, defies the western dichotomy of spirit/matter or natural/supernatural in much the same way that some scholars think Paul's version of the resurrected body defies the same dichotomies. ${ }^{63}$

62 Nürnberger, The Living Dead and the Living God, 27, 87.

63 Dale B. Martin argues that when Paul speaks of the resurrected body as being a Spiritual Body, by that he does not mean "spirit" in the modern sense of the word. He argues that Paul lived and wrote before the distinction between natural and supernatural was made, and that "spirit" would have referred to something material, but softer, lighter and more reified, much like air, or even light. For a full description of this view see D. B. Martin, The Corinthian Body (Durham: Yale University Press, 1995), 21-25; 104-136. For a response to Martin's exegesis, see David's Wilkinson's Christian Eschatology and The Physical Universe (London: T\&T Clark International, 2010), 92-101. 
Thirdly, in both there is a sense in which the one who died is experienced in the present, albeit in very different ways: one by being raised from the dead, and the other by becoming an Ancestor

\section{Divergences}

The first divergence is that African Ancestors are not believed to have been raised from the dead. Some even suggest that the idea of someone being raised from the dead would, in traditional African thought, possibly be considered the worst kind of witchcraft. ${ }^{64}$ The Ancestor is considered dead, but death is not seen as the annihilation of the individual. The notion of the resurrection of Jesus, on the other hand, means that Jesus is not dead anymore, but is alive.

The second divergence, which has been discussed above, is that not everyone becomes an ancestor after death. People who die of unnatural causes and have not gone through all the rites of passage and major life milestone, did not become Ancestors. Even Jesus, having died by crucifixion, would have not been considered an ancestor.

The third divergence is that not everyone becomes an Ancestor in traditional African thought; while in the New Testament notion of the resurrection, Christ is the first fruits, or the first to rise from the dead. Others will rise in the same way at the Parousia, no matter how they die (natural causes or unnatural). In fact, as has been mentioned above, the notion of Resurrection of the dead arose in Judaism when there were Jews who resisted Hellenization in order to hold to Torah observance and were killed for it. In other words, the notion of resurrection did not emerge in Judaism as a result of those who died of natural causes, but rather because of questions about the righteousness of God in the light of the execution (death by unnatural causes) of those considered faithful.

I point out these similarities and divergences in order to avoid naively conflating there two different beliefs, with differing histories into the same thing; while at the same time allowing the African traditional concept of an ancestor to contribute to the remembering of the dead that constitutes

64 Vellem, “Serithi/Isidima,” 317-318. 
weak theology. The sacredness of the community for the African context can be helpful in the endeavour to remember the dead. The living must be in community with the dead and must not resign them to annihilation. Also, if the notion of remembering the dead (which I have demonstrated is central to ancestral veneration) is brought into conversation with the Christian notion of a general resurrection, then even those African's who died of unnatural causes, particularly those which constitute injustice to black Africans, can be remembered even though it would not be by the traditional way - by becoming Ancestors.

Now I will synthesise what has been gleaned from the discussion of ancestoral veneration with resurrection as interpreted through weak theology, by using the resurrection of Jesus as the concrete example of a resurrection.

\section{Resurrection appearances}

In the New Testament, three days after the Crucifixion of Jesus, he appears to his followers alive. ${ }^{65}$ The different authors of the New Testament who describe the resurrection give differing details, but they all agree that Jesus was raised, and that he appeared to his followers. Moltmann states that by virtue of the fact that these were described as appearances, that they harkened back to the Old Testament revelation formula that was often used in theophany accounts. ${ }^{66}$ Even when these experiences are being understood as appearances of the risen Christ, interpretation - and at that,

65 Moltmann, The Way of Jesus Christ, 215-216. There are New Testament Scholars who doubt the historicity of the part of the tradition that claims that Jesus appeared to his followers three days after his crucifixion, as well as the historicity of an empty tomb, but do not doubt the historicity of experiences that Jesus' followers had after his death which they understood as appearances of the risen Jesus. For an example, see John Dominic Crossan's Jesus: A Revolutionary Biography (New York: Harper One, 1994), 179-216.

66 Moltman, The Crucified God, 235-236; Way of Jesus Christ, 218-219.Whenever God, or something/someone important in relation to God is seen in the Old Testament, that seeing is described with words such as "appear" or "shown," words which imply that the one who is seeing is not responsible for what he or she is seeing, but that God is showing it - God is either revealing Godself, or God is revealing someone or something else. 
theological interpretation - has already began. ${ }^{67}$ The naked facts of what the disciples experienced are inaccessible by historical means.

Moltmann then posits that if we examine the way that the appearances of Christ were interpreted by his follower, three dimensions are discovered in the structure of their interpretations. ${ }^{68}$ Of the three, my interest in this study is the second: "The second is retrospective: they recognized him from the marks of the nails and in the breaking of the bread: the One who will come is the One crucified on Golgotha." 69 The recognition here spoken of is helpful in developing what I have been referring to as remembering the dead. The concerns of this kind of recognition are not limited to recounting the past, by they also have to do with the future of the one who was killed. The victim has a future and is not imprisoned to a past which is ruined time. Also, by virtue of the fact that it is retrospective, it does not leave the painful memories of the of the past to remain as memories of hopelessness and despair but changes them even if that is only by changing the way the victim is perceived. We see this in Christ when we start at the resurrection and move back to his life: "if Jesus is now Lord in the Spirit - who was he in his earthly life and in his suffering and death on the cross?"70 In fact, Moltmann even takes this retrospectivity to be present in the recollections about Jesus that came to form part of the New Testament gospels:

Primitive Christian recollections of Jesus were determined from the start by the experience of his resurrection through God. That was the only reason why his words and his story were remembered and why people were concerned with him. Even today, it is doubtful whether there is any other adequate reason for being concerned with the person and history of Jesus Christ which lie so far back in the past. As a merely historical person he would long have been

67 The Way of Jesus Christ, 216, 219.

68 "The first is prospective: they saw the crucified Christ as the living One in the splendour cast ahead by the coming glory of God. The second is retrospective: they recognized him from the marks of the nails and in the breaking of the bread: the One who will come is the One crucified on Golgotha.

The third is reflexive: in this seeing they perceived their own call to the apostolate," in Moltmann, The Way of Jesus Christ, 220.

69 Ibid., 220.

70 The Crucified God, 256. 
forgotten, because his message had already been contradicted by his death on the cross. ${ }^{71}$

If this logic is followed, then what we have in the New Testament gospels is not the history of Jesus, but rather it is a continuing of the experiencing or even the encountering of Jesus, even in ways that now contradict his historical crucifixion - they killed him, but God raised him. This is the recollection of ruined time, but also the hoping and praying for new time, the time of resurrection. This is to save the past, not to change it.

What weak theology is concerned with is not whether Jesus literally and physically rose from the dead. The concern for weak theology is that resurrection means that the Jesus who was crucified can be experienced in new ways. The challenge that is being issued by this challenge is that we look at the instances of ruined time in the history of South Africa, such as Marikana, the Sharpeville massacre along with apartheid as a whole, and colonialism, and to imagine the possibility that we have not understood who all those unnamed victims were, much like the disciples did not understand Jesus when he walk with them; or even like the unknown homeless people who were murdered by a serial killer in Tshwane who seems to have only been targeting homeless people in $2019 .{ }^{72}$ The challenge is for us to remember the dead, not in restrictive ways: the objective is not modern historiography, though that too is a valid and necessary endeavour. The objective being described here is to remember the dead so that the dead can have a future; to remember the dead even in ways that confront and even dare to contradict the historical fact of their death: Rome killed Jesus, but God raised him; yes they (Imperialistic Colonial Empires) have killed them, but what will God do? As has been stated above, the objective here is not to alter or annul the past, but to save it. For weak theology it is not about whether or not God will actually do something (it is not about thinking of God as an agent), but about the stubborn refusal to forget the dead and to resign them to their historical fate, a refusal that is found at

71 Ibid., 228.

72 A. Mitchley, "Homeless killings: What we know so far about the Tshwane murders (2019).” [Online] Available: https://www.news24.com/SouthAfrica/News/homelesskillings-what-we-know-so-far-about-the-tshwane-murders-20190702 
the moment where eschatological God talk meets the corpses produced by empire.

\section{Conclusion}

This article sought to bring Caputo's phenomenological approach to the resurrection in conversation with the Africa Traditional practice of venerating the Ancestors, so as to approach a theological way of remembering the dead victims of past injustices in a way that differs from historiography. This is theology from below because the dead no longer have a voice to speak for themselves, and so this is theology attempting to go six feet under to do just that. This is in the hope that addressing these past injustices will open up the possibility of new South Africa that radically breaks with the old South Africa.

\section{Bibliography}

Biko, S., 1978. I Write What I Like. Johannesburg: Picador Africa.

Caputo, J.D., 1987. Radical Hermeneutics: Repetition, Deconstruction, and the Hermeneutical Project. Bloomington: Indiana University Press.

Caputo, J.D., 2006. The Weakness of God. Bloomington: Indiana University Press.

Caputo, J.D., 2007. Bodies Still Unrisen, Events Still Unsaid. Journal of Theoretical Humanities, pp. 73-86.

Caputo, J.D., 2013. The Insistence of God: A Theology of Perhaps. Bloomington: Indiana University Press.

Caputo, J.D., 2019. Cross and Cosmos: A Theology of Difficult Glory.

Bloomington: Indiana University Press.

Copeland, M.S., 2010. Enfleshing Freedom: Body, Race, and Being. s.l.:Fortress Press.

Crossan, J.D., 1994. Jesus: A Revolutionary Biography. New York: Harrper One.

Martin, D.B., 1995. The Corinthian Body. Durham: Yale University Press. 
Martin, D.B., 2017. Biblical Truths: The Meaning of Scripture in the Twenty-first Century. New Haven and London : Yale Unovesity Press.

Mbiti, J.S., 1975. Introduction to African Religion. Long Grove: Waveland Press.

Mitchley, A., 2019. Homeless killings: What we know so far about the Tshwane murders. [Online]

Available: https://www.news24.com/SouthAfrica/News/homeless-

killings-what-we-know-so-far-about-the-tshwane-murders-20190702

Moltmann, J., 1973. The Crucified God. 40th Anniversary ed.

Minneapolis: Fortress Press.

Moltmann, J., 1993. The Way of Jesus Christ. Minneapolis:Fortress Press.

Moltmann, J., 1996. The Coming of God. Minneapolis: Fortress Press.

Mtuze, P., 2003. The Essence of Xhosa Spirituality and the Nuisance of Cultural Imperialism. Johannesberg: Vivlia.

Nürnberger, K., 2007. The Living Dead and the Living God.

Pietermaritzburg: Cluster Publications.

Pannenberg, W., 2007. Modernity, History, and Eschatology . In: The Oxford Handbook of Eschatology . s.l.:s.n., pp. 493-498.

Stinton, D.B., 2004. Jesus of Africa. New York: Orbis Books.

Vellem, V., 2010. Serithi/Isidima. Scriptura, pp. 314-321.

Wilkinson, D., 2010. Christian Eschatology and The Physical Unverse. London: T\&T Clark International. 